\title{
Hydrological Research at National Institute of Hydrology, India
}

\author{
C. P. Kumar
}

\begin{abstract}
The National Institute of Hydrology (NIH) is a premier research Institute in India in the area of hydrology and water resources. The Institute was established in 1978 with the main objective of undertaking, aiding, promoting and coordinating systematic and scientific work in all aspects of hydrology. The Institute has its headquarters at Roorkee (Uttarakhand), four regional centres at Belagavi, Jammu, Kakinada and Bhopal and two centres for flood management studies at Guwahati and Patna. The Institute is well equipped to carry out computer, laboratory and field oriented studies. This article presents an overview of research activities being undertaken by the Institute.

Index Terms - Groundwater, Hydrology, Research,
\end{abstract} Roorkee, Water Resources.

\section{INTRODUCTION}

The National Institute of Hydrology is a premier research organization in India working in the area of hydrology and water resources. It was founded on 16 December, 1978 as an autonomous body registered under the Registration of Societies Act of 1860 under the Ministry of Irrigation (now renamed as Ministry of Water Resources, River Development \& Ganga Rejuvenation), Government of India, at Roorkee. The Institute is fully funded by Ministry of Water Resources, River Development \& Ganga Rejuvenation. The main objectives of the Institute are:

i. to undertake, aid, promote and coordinate systematic and scientific work in all aspects of hydrology;

ii. to cooperate and collaborate with other national and international organizations in the field of hydrology;

iii. to establish and maintain a research and reference library in pursuance of the objectives of the Society and equip the same with books, reviews, magazines and other relevant publications; and

iv. to do all other such things as the Society may consider necessary, incidental or conducive to the attainment of the objectives for which the Institute has been established.

C. P. Kumar, Scientist 'G', National Institute of Hydrology, Roorkee - 247667, India
Since 1978, the Institute has expanded with addition of six regional centres in different hydrological regions of India. Two of these regional centres were later renamed as Centres for Flood Management Studies.

The research activities of the Institute are being carried out in six scientific divisions at the headquarters at Roorkee, two Centres for Flood Management Studies at Guwahati and Patna and four Regional Centres at Belagavi, Jammu, Kakinada and Bhopal. The Institute's research and other technical activities are monitored and guided by the Technical Advisory Committee, Working Group (for headquarter) and Regional Coordination Committees (for Regional Centres and Centres for Flood Management Studies).

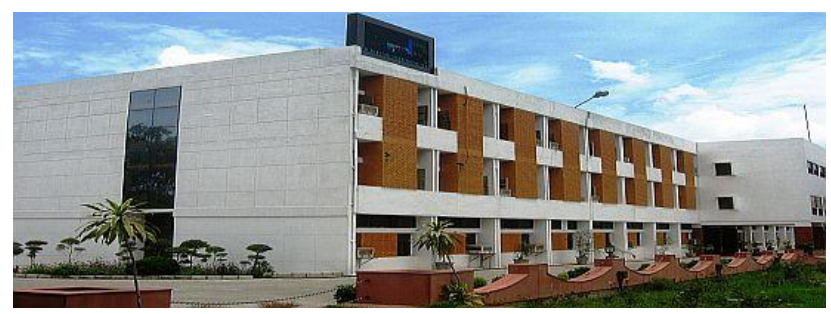

The Institute acts as a centre of excellence for transfer of technology, human resources development and institutional development in specialized areas of hydrology and conducts user defined, demand-driven research through collaboration with relevant national and international organizations.

The Institute vigorously pursues capacity development activities by organizing training programs for field engineers, scientists, researchers, NGOs etc. The Institute is focusing studies and R \& D in the thrust areas of impact of climate change on water resources; integrated water resources management; groundwater modelling and management; flood and drought management; regional hydrology; hydrology of extremes; reservoir/lake sedimentation; watershed hydrology; and water quality assessment in specific areas.

\section{SCIENTIFIC DIVISIONS AT ROORKEE}

The scientific activities of the Institute are carried out under the scientific divisions and regional centres. Details of the scientific activities of the six divisions at headquarters (Roorkee) are given below. 


\section{A. Environmental Hydrology}

The division aims to undertake, aid, promote and coordinate basic, applied and strategic research in the area of environmental hydrology contributing to sustainable water resources development and management. The thrust areas of research in the division include environmental monitoring including natural contaminants, point and non-point source pollution, adsorption kinetics and water sediment systems, transport and sedimentation of pollutants, contaminant transport modelling, metal speciation/fractionation, groundwater quality and aquifer contamination, low cost treatment/remediation technologies, water quality and human health, environmental modelling, water quality and climate change, geo-microbial pollution, lake ecosystems and river bank filtration for sustainable water supply.

Research activities vary from those oriented towards specific problems, often at specific sites, to those focused on increasing the knowledge and understanding of fundamental processes that affect the availability, movement and quality of water. This include investigations of the fate and transport of hazardous substances, investigations of chemical, biologic and microbiologic processes that affect quality of water and research into the complex hydrologic phenomena of lakes and streams. All research is aimed at improving understanding of how the quality and quantity of water are affected by the natural environment and the anthropogenic activities.

In addition to the above and keeping in view the complexity involved in chemical-soil-groundwater interactions, groundwater quality studies related to drinking water, hazardous wastes, impact of pesticides, insecticides and other agricultural chemicals, salinization and microbial pollution in shallow wells etc. need to be addressed through multidisciplinary approach.

To pursuit the above research, the division has a well equipped Water Quality Laboratory with the state-of-art monitoring and analytical instruments powered by a topof-line team of scientists and supporting scientific and technical staff. Sophisticated and well equipped Water Quality Laboratory is the major asset for research and development in the area of Environmental Hydrology in water sector.

The laboratory is fully capable to identify and quantify physical, chemical and bacteriological parameters in various water bodies like rivers, lakes, reservoirs, wells, aquifers, canals etc. The laboratory has facilities and capabilities to determine various water quality constituents including major and minor ions, trace elements, pesticides, hydrocarbons and other organic compounds and bacteriological parameters.

\section{B. Ground Water Hydrology}

Providing efficient and effective methodologies and technologies for sustainable groundwater resources development and management is vision of this division. Some of the emerging areas in the field of groundwater hydrology needing inputs to modern science include groundwater storage and resource estimation; groundwater modelling and management; coastal aquifer dynamics; surface water and groundwater interaction; hard-rock and karst hydrology; groundwater sustainability on supply and demand; managed aquifer recharge for groundwater augmentation; river-aquifer interactions for bank filtration and baseflow sustainability; re-use of treated effluents for managed aquifer recharge (MAR); contaminants mobilization in groundwater system; threat of emerging contaminants in groundwater; groundwater protection against contaminants, and impact of environmental changes on groundwater resources.

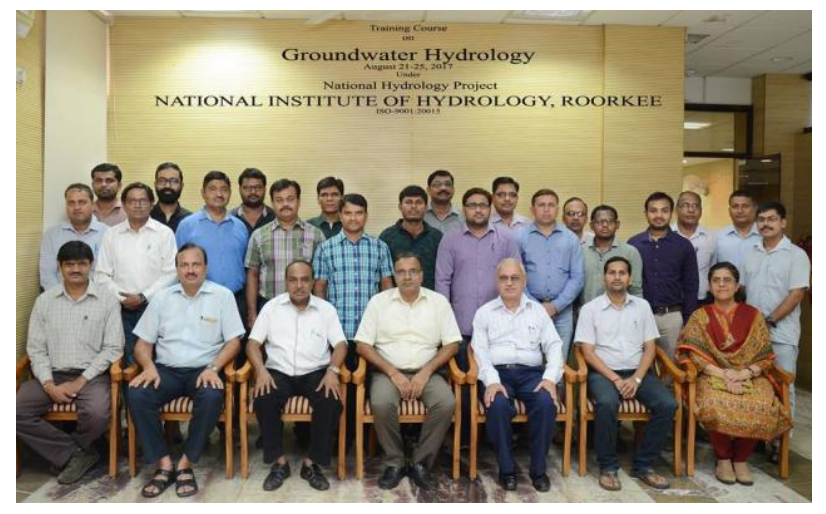

Keeping in view of these thrust areas, the Ground Water Hydrology division is pursuing the basic and applied research pertaining to various aspects of groundwater hydrology such as, aquifer parameter estimation; aquifer responses due to untoward stresses; groundwater assessment, modelling and management; coastal groundwater dynamics; contaminant transport modelling; managed aquifer recharge; bank filtration; impact of climate change on groundwater resources etc. The division has two technical services facilities: "Soil Water Laboratory" and "Centre of Excellence for Advanced Groundwater Research" which is comprised of two units - 'Numerical Groundwater Modeling Unit' and 'Indo-German Competence Centre for Riverbank Filtration'. All these facilities are well equipped with advanced tools, and instrumentation required for groundwater monitoring and assessment, aquifer hydraulic parameters characterization, groundwater quality detection, modelling and management of groundwater.

\section{Hydrological Investigations}

Hydrological Investigations division conducts field and laboratory based hydrological studies for sustainability of water resources using advanced isotope 
techniques, geophysical and hydrological techniques, in the areas of (i) spring management, (ii) lakes and reservoirs studies, (iii) water management in mine areas, (iv) dynamics of deeper aquifers, (v) groundwater management, and (vi) development / implementation of modern technology for measurement of various data.

The division also has two state-of-art laboratories attached to it, namely, (i) Nuclear Hydrology laboratory and (ii) Hydrological Instrumentation laboratory. The Nuclear Hydrology laboratory has facilities to measure different types of radio-active and stable isotopes while Hydrological Instrumentation laboratory has state-of-art hydro-meteorological instruments for demonstration and measuring various hydro-meteorological parameters.

\section{Surface Water Hydrology}

A comprehensive understanding of various hydrologic processes associated with surface water hydrology is a pre-requisite for optimal planning, development and management of water resources for sustainable development and well being of the society. The Surface Water Hydrology division has been carrying out R \& D on various aspects of surface water hydrology. The thrust areas of research of the division include: (i) water availability analysis, flow duration curve analysis and environmental flow requirement, (ii) flood estimation, (iii) flood routing, (iv) hydrological modelling, (v) structural and non-structural measures of flood management, (vi) snow and glacier melt monitoring and modeling, (vii) urban hydrology, (viii) watershed management studies, (ix) socio-economic aspects of flood disasters, (x) drought mitigation and management, and (xi) impact of climate change on water resources.

\section{E. Water Resources Systems}

There are a number of concerns in management of water resources in India: (a) we have large spatial and temporal variability in availability of water and mismatch with demands which results in deficits, disasters such as floods, droughts, soil erosion and reservoir sedimentation, (b) water stress in large parts of our country is rising, triggered mainly by rapid growth in population, irrigation needs, industrialization, urbanization and climate change, and c) lack of accessible databases on hydrology and related sectors. Water resources projects are frequently planned in isolated manner without giving due consideration to optimum utilization and environment sustainability. The division is working towards finding solution to these issues.

Vision of the division is to develop and apply methodologies for analysis of reservoirs, river basin planning, operation of irrigation systems, snow glacier studies and watershed problems; and applications of advanced tools such as remote sensing, GIS, ANN and DSS etc. in solving water resources problems.

The division is determined to provide feasible solutions to the water problems by developing and applying methodologies for integrated and optimum management of water resources at the basin scale; developing and applying remote sensing and GIS tools to provide inputs for hydrological modeling, display and visualization of results; assessment of environmental flows; understanding and assessing the possible impacts of climate change on water resources; snow/glacier/permafrost investigations and modelling studies; developing user-friendly software tools for analysis, management, and information dissemination pertaining to water systems; developing web-based water resources information systems; water governance; and applying emerging techniques to solve water management problems. In the recent past, the division has taken up a number of projects in some of the above areas. The division has a well-equipped Remote Sensing and GIS Laboratory with popular software like ERDAS, Arc GIS, etc.

\section{F. Research Management and Outreach Division (RMOD)}

Vision of this division is an effective dissemination of scientific output of the Institute so as to improve scientific delivery and outreach of the Institute for the benefit of various stakeholders.

RMOD basically performs the activities related to research management and techno-administration. Major functions of the division include: Thematic consultations, lectures, etc.; Policy papers, policy briefs, science-policycommunity interface; Outreach activities and capacity building programmes; S\&T dissemination; ISO certification; Publication of NIH newsletter; Technical/scientific meetings (Technical Advisory Committee, Working Group); Collaboration with research/academic institutions; Promotion of international cooperation; Preparation of documents (e.g. annual action plan, outcome budget, performance budget, Result Framework Document, Expenditure Finance Committee Memorandum) etc. It also carries out research on topics/themes which require research and/or project management inputs.

\section{REGIONAL CENTRES}

In order to deal with specific hydrological problems in different regions of the country and for providing effective interaction with the States, the Institute has established following two Centers for Flood Management Studies (CFMS) and four Regional Centres. 


\section{A. Centre for Flood Management Studies, Guwahati}

The North Eastern Regional Centre (NERC), Guwahati catering for seven North-East states, Sikkim and parts of West Bengal (Teestha basin) was established in August 1988 at Guwahati and was working for various water resources problems of the region. As per five-year action plan of $11^{\text {th }}$ plan period (2007-2012), the Centre had worked in the following thrust areas during $11^{\text {th }}$ plan period: (i) flood estimation and routing, (ii) structural/ non-structural measures for flood management, (iii) integrated watershed management for flood control, (iv) hydrological database management system, (v) drainage congestion and erosion problems, (vi) water quality problems, and (vii) socio-economic aspect of flood disaster, and viii) technology transfer. Keeping in view the importance of above thrust areas, the Centre continued to work in the above thrust areas during the $12^{\text {th }}$ plan period $(2012-2017)$ with more emphasis on pilot basin studies. The Centre has got long term ongoing program of representative basin studies and has procured advanced software for flood studies and packages for GIS.

\section{B. Centre for Flood Management Studies, Patna}

Centre for Flood Management Studies (CFMS), formerly known as the Ganga Plains North Regional Centre (GPNRC) was established in May 1991. Based upon the hydrological problems of the region, this Centre is focusing on the studies related to flood estimation, flood forecasting, remote sensing and GIS based studies, water logging and drainage congestion problems, evaluation of geomorphologic characteristics of rivers, sedimentation/erosion problems, preparation of flood plain zoning maps, urban hydrology studies, water quality and environmental pollution, impact of climate change on water resources of Ganga basin. In addition to field and laboratory based studies, the Centre is also involved in technology transfer activities and collaboration with various concerned local organizations.

\section{Hard Rock Regional Centre, Belagavi}

About $67 \%$ area of India is occupied by hard rock terrain. This region frequently experiences drought and at times flood also. Groundwater is one of the most dependable water resources in the region. Over the last decade, the usage of groundwater has increased exponentially causing lowering of groundwater levels. On the other hand, increased anthropogenic activities in the region have resulted in dramatic changes in the land use and land cover. This has strongly affected the water availability of the region. These problems are further complicated by the changes observed in the rainfall and meteorological parameters over the region. Keeping the problems of the peninsular India in view, the Hard Rock Regional Centre has been carrying out studies related to water availability of the hard rock region, forest hydrology, groundwater, water logging and salinity studies. However, looking at the present and future needs of the region, drought studies, urban hydrology and the impacts of climate change on water resources sector have also been added.

\section{Western Himalayan Regional Centre, Jammu}

The major objective of Western Himalayan Regional Centre (WHRC), located at Jammu, is to carry out hydrological research for the Western Himalayan region of the country. This region is marked with steep mountains that influence the climatic conditions of northwest India and is the main source of water supply for Indo-Gangetic plains. The states of Jammu \& Kashmir, Himachal Pradesh and hilly portion of Uttarakhand constitute the jurisdiction of this Centre.

The thrust areas of studies and research at WHRC include representative basin studies, water availability studies, hydrology of lakes, water quality studies, flood and related studies, snow and glacier-melt studies, soil erosion and sedimentation studies, effects of afforestation/ deforestation on the hydrological regime, hydrological network improvement and instrumentation, and remote sensing applications.

The hydrological problems of the Himalayan region are different from the plain areas due to variation in topography, geology, climate, land use, soil, etc. The Western Himalayan region in particular faces a variety of hydrological problems which mainly include: water scarcity problems; floods generated from heavy rainfall, glacial lake outbursts and cloud bursts; deterioration of lakes; water quality problems; soil erosion and sedimentation; decreasing water availability; lack of scientific planning for optimum use of water at basin scale; lack of adequate trained personnel for scientific planning and development constraining good water management; lack of organized hydrological database resulting from insufficient observation network, manual instrumentation coupled with poor recording/processing facilities and data dissemination; as well as low public awareness about the scarcity and economic value of water resulting in its wastage and inefficient use.

\section{E. Deltaic Regional Centre, Kakinada}

East coast of India is rich in utilizable water resources as most of the central and peninsular rivers drains towards the Bay of Bengal through important river deltas of Ganges, Mahanadi, Godavari, Krishna and Cauvery. Approximately $25 \mathrm{~km}$. width of the east coast of India is vulnerable to cyclones hazard and the risk is particularly severe at the mouths of rivers and estuaries. On an average, four severe cyclonic storms form in the Bay of Bengal every year. Due to cyclones and floods, the coastal areas are frequently inundated, thus causing loss 
of crops, human lives etc. Groundwater problems are also significant in coastal areas apart from the surface water problems. Backwater through the streams and rivers, aquaculture practices, excessive pumping of groundwater are the main sources of salinity contamination in the shallow aquifers. Other than the salinity, groundwater and surface water are also deteriorating due to industrial effluents, poorly treated sewage, irrigation return flows, and unsatisfactory household and community sanitary conditions. Therefore, few thrust areas have been identified after interacting with various water resources agencies in the region. The main thrust areas are: Urban hydrology, Real time flood forecasting, Impact of climate change on river flows, Flash floods in ungauged basins, Sedimentation of reservoirs, Point and non point groundwater source contamination, Saltwater intrusion modelling, Time series and Rainfall-runoff modelling. The Centre is also equipped with Soil and Water Quality Laboratory, GIS and remote sensing tools and other hydrological software for analyzing field problems.

\section{F. Central India Hydrology Regional Centre, Bhopal}

Central India Hydrology Regional Centre (CIHRC), Bhopal initially known as Ganga Plains South Regional Center was established at Sagar on $1^{\text {st }}$ December 1995 with a specific objective to undertake, aid, promote and coordinate systematic and scientific studies in all aspects of hydrology in north flowing tributaries of the Ganges. The Centre functioned from a private rented building at Sagar till October 31, 2012 and was relocated to Madhya Pradesh WALMI Campus, Bhopal since November 1, 2012 with the same mandate. Since the Centre is located in Central India, it has been renamed as "Central India Hydrology Regional Centre" in the year 2015. This Centre has been set up to carry out research studies in various hydrological problems of basins and sub-basins of north-flowing tributaries of the Ganges namely Banas, Chambal, Kalisindh, Betwa, Dhasan, Ken, Tons, Son etc. The jurisdiction of CIHRC, Bhopal covers major part of Madhya Pradesh, southern part of Uttar Pradesh and south-east Rajasthan, northern part of Chhattisgarh and south-west part of Bihar.

The area covered by the Centre is primarily dependent on rainfed agriculture. Lack of appropriate water resource management, degraded watersheds, recurrent droughts, excessive soil erosion, groundwater depletion, deterioration of water quality and reduction of forest cover have given rise to inadequate water availability, reduced crop yield and exacerbated poverty in this region. Under these circumstances, sustainable management of water resource including its quality is one of the key challenges in the R \& D activities. The Centre has thus aimed to carry out scientific research to develop appropriate methods and methodologies for sustainable management of water resources including drought, artificial recharge, reservoir sedimentation, command area management, etc. in its jurisdiction. The Centre has also focus towards conducting research in areas related to impacts of climate change on water resources in river basins in Central India.

\section{SPONSORED AND CONSULTANCY PROJECTS}

For past many years, the Institute has been carrying out projects sponsored by International and National agencies. It is also providing solution to problems faced by industry and field organizations through consultancy projects. The consultancy projects are being referred by State Governments, Public Sector Undertakings, and also by private companies. During the last three years, the Institute has completed following sponsored and consultancy projects.

\section{A. International Sponsored Projects}

1. Review of Groundwater Resources in the IndoGangetic Basin: A Case Study on Resilience of Groundwater in the Punjab to Withdrawal and Environmental Change

2. Assessment of Baseflow and Its Impact on Water Quality in Part of Satluj River in India Using Environmental Isotope and Age Dating Techniques

3. Saph Pani - Enhancement of Natural Water Systems and Treatment Methods for Safe and Sustainable Water Supply in India

\section{B. National Sponsored Projects}

1. Preparation of Ganga River Basin Environment Management Plan (GRBEMP)

2. Glaciological Studies of Phuche Glacier, Ladakh Range, India

3. Assessment of Environmental Flows for Himalayan Rivers

4. Integrating Hydrology, Climate Change and IWRM with Livelihood Issues: Development of Methodology and a DSS for Water-scarce Bundelkhand Region in India

5. Low Cost Technology for Purification of Arsenic and Microbes Contaminated Water Using Nanotechnology

6. Ionic Enrichment of Glacial Sediment and Melt Water of Gangotri Glacier

C. Consultancy Projects 
1. Hydrological Study of Ambuja Cement's Marwar Mundwa Cement Project, Mining Area and surroundings near Mundwa Village in Nagaur District of Rajasthan

2. Hydrological Area Drainage Study \& Design of Drainage System for GHAVP - 1 to 4 Project Site

3. Area Drainage Study for Plant and Ash Dyke for Gajmara Super Thermal Power Project (4 x $800 \mathrm{MW})$

4. Site Specific Area Drainage study for Plant and Ash Dyke for Khargone Super Thermal Power Project $(2$ x $660 \mathrm{MW})$

5. Environmental Flow Assessment for HEO 240 MW, Arunachal Pardesh

6. Hydrogeological Study for Ash Pond of 2 x 525 MW Maithon Power Ltd and an Abandoned Coal Mine, Distt Dhanbad, Jharkhand

7. Area Drainage Studies for Power Projects of NTPC - SAIL Power Company Pvt Ltd at Jagdishpur SAIL Unit in Distt Sultanpur (UP)

8. Impact Assessment of Ash Pond on the Groundwater Quality in the Surrounding Villages of NTPC Simhdri through Stable Isotopic Studies

9. Design Flood Estimate for Pagal Nallah, Leh

10. Possible Impact of Construction Activities in Kansal Area (Mohali) on Water Flow to Sukhna Lake in Chandigarh

11. Glacial Lake Outburst Flood (GLOF) Study For Jelam Tamak H.E. Project

12. Snow Line Estimation Snowmelt Runoff Study and Glacial Lake Outburst Flood Study for Chamkharchhu H.E. Project

13. Environmental Flow Assessment (Hydrology) of Hydroelectric Projects in AlkanandaBhagirathi Basin up to Devprayag

14. Drainage Area Mapping and Hydrological Studies in and around Gurha (W) Lignite Block in Kolayat Tehsil of Bikaner, Rajasthan

15. Cumulative Impact Assessment of Alaknanda and Bhagirathi including Tributaries

16. Identification of Source of Seepage/Leakage around Lake Nainital, Uttarakhand
17. Estimation of Sediment Rate at Proposed Jalleru Reservoir, Andhra Pradesh

18. Environmental Flow Study of Nakthan HEP (520 MW) Project in Himachal Pradesh

19. Yield Study of Yettinahole Project, Kakinada

20. Isotopic Characterization of Groundwater of District Raigarh

21. Water Safety Impact Assessment through Sanitary Improvement of India Mark 2 Hand Pumps in Moradabad, UP

22. Ganga Aquifer Management for Ecosystems Services (GAMES)

23. Feasibility of Infiltration Wells for River Bank Filtration of Srinagar, Gauchar and Karnprayag in Uttarakhand

24. Assessment of Groundwater Contamination due to Past Storage of Spent Wash in Kachacha Lagoons and Suggesting Remedial Measures

25. Assessment of Environmental Flow Requirement in River Parbati and Tosh at Nakthan Project Site

26. Asessment of Environmental Flow Requirement in River Satluj at Shongtong Karchham Project Site

27. Hydrological Study for Rural Drinking Water Supply Options in Part of Bundelkhand Region of UP

28. Desk Study of Dam Break Analysis for Kudgi STPP, Stage-1 (3 x 800 MW)

29. Hydrodynamic Modelling of River Viswamitri for Preparation of Flood Mitigation Plan for Vadodara City

30. Dam Break Studies of Baira Dam, Baira Siul Power Station, Surangani, District Chamba (HP)

31. Dam Break Study of Chamera-II Dam Chamba (Himachal Pradesh)

32. Engineering Services for Water Availability Studies and Area Drainage Studies including Hydrological Design of Site Area Drainage for Chutka Site in Mandla District, M.P.

33. Petroleum Product Contamination at Akolner Village, District Ahmednagar, Maharashtra and Suggesting Remedial Measures 
34. Dam Break Analysis of Dams in Sharavathy and Varahi River Basins

35. Hydrogeological and Isotopic Investigations of Districts Lalitpur and Jhansi of Bundelkhand Region

36. Estimation of Canal Seepage and Groundwater Recharge using Isotopic Techniques in the Chajlet Block, Moradabad district, UP

37. GIS Map for the Entire Catchment of Sapta Kosi High Dam Multipurpose Project and Sun Kosi Storage-cum-Diversion Scheme, Nepal

38. Dam Break Analysis for Teesta Low Dam - III Power Station Barrage

39. Dam Break Analysis for Preparation of Emergency Action Plan and Inundation Map (Teesta V)

40. Flood Plain Zoning for Safe Habitation and Commercial Construction along the River Banks in Uttarakhand

41. Hydrological Studies and Multi-Reservoir Simulation for Proposed Mahanadi-Godavari Link (Flood Moderation Scheme)

42. Hydrological Studies for Burhi Gandak-NoonBaya-Ganga Link

\section{CONCLUDING REMARKS}

With the dedication and innovative ideas put forward by the scientists and hard work of the employees, NIH has achieved commendable progress. It is expected that the Institute will continue to attain higher levels of achievements in the years to come. This article provides a glimpse of the research activities of the Institute and the contributions made by it in the field of hydrology and water resources during last few years. Further information about the Institute is available at http://www.nihroorkee.gov.in/

\section{REFERENCES}

[1] Annual Report (2014-15), National Institute of Hydrology, Roorkee - 247667 (Uttarakhand).

[2] Annual Report (2015-16), National Institute of Hydrology, Roorkee - 247667 (Uttarakhand).

[3] NIH Website: http://www.nihroorkee.gov.in/

[4] https://en.wikipedia.org/wiki/National_Institute_of_Hydrology 